\title{
Right-wing Populist Parties and the Mellowing Down of Euroscepticism in Eastern Europe under the Influence of Europeanization
}

\author{
Philip Dandolovi \\ Department of Politics, Languages \& International Studies, University of Bath, England
}

Copyright $(2017$ by authors, all rights reserved. Authors agree that this article remains permanently open access under the terms of the Creative Commons Attribution License 4.0 International License

\begin{abstract}
This paper examines two cases in which the European Union (mainly through its normative influences) reduces the playing space for nationalist parties or is a factor in their declining electoral fortunes, which nonetheless does not result in a marked transformation of the parties' ideologies in a staunchly anti-EU fashion. The Ataka party in Bulgaria and the HZDS in Slovakia both exemplify the principle of charismatic leadership and are regarded as strongly focused on nationalism, while also exhibiting populist and anti-establishment leanings. Ataka reached the height of its popular support between the mid and late 2000s and is currently represented in the National Parliament of Bulgaria. On the other hand, the HZDS was a significant factor in Slovak politics between the Velvet Divorce and the late 1990s, but is no longer active, as it was dissolved in January 2014. The conclusion reached by comparing the fortunes of these factions is that encouraging the imposition of a direct or indirect "cordon sanitaire" by the mainstream parties on anti-establishment ones under the direction of the EU could actually have a beneficial effect in terms of altering the party's orientation and moving its opposition to the EU within the "soft Euroscepticism" spectrum.
\end{abstract}

Keywords Euroscepticism, Europeanization, Nationalism, Populism, Eastern Europe, Slovakia, Bulgaria

\section{Introduction}

The various manifestations of Euroscepticism and the strategies through which the EU manages to "insert itself" into the context of domestic political competition continue to be a topic of salience from the standpoint of both policy-makers and regular citizens. In a time period that has seen a flurry of networking and electoral successes on the part of political parties with an explicitly anti-EU profile (mainly in Western Europe), [1] this study sets the clock back and looks at the Eurosceptic undercurrents in the 1990s and 2000s in the case of two Central \& Eastern European member states of the EU that have successfully escaped from the shadow of Euroscepticism and are currently characterized by a pro-European consensus at the political level. In the aftermath of the collapse of totalitarianism in 1989 , the strong influence of pro-EU voices notwithstanding, [2] the firm anchoring of Bulgaria and Slovakia into the EU family of nations was far from guaranteed. However, a combination of factors such as the skillful maneuvering of local politicians, the EU's instrumental and normative leverage, a serious commitment displayed by civil society actors towards achieving membership as well as a somewhat surprising ability of formerly staunchly Eurosceptic parties to reform and adapt, eventually brought the EU question out of the sphere of conflict politics.

\section{Ataka}

The Bulgarian nationalist-populist Ataka party was established in April 2005 as a result of the merger of the National Movement for Saving the Fatherland (NMSF), the Bulgarian National-Patriotic Party (BNPP), and the Union of Patriotic Forces (UPF).[3] The main public relations anchor of Ataka at the time was SKAT television (which had come to life in 1992 and was notable for its nationalist orientations).[4, p.14] SKAT is currently no longer affiliated with Ataka and has thrown its weight behind its own nationalist party - the National Front for the Salvation of Bulgaria (NFSB), which is (as of 2016) chaired by Valeri Simeonov. [5]

In addition, a weekly newspaper under the name of Nova Zora (New Dawn) closely linked with Ataka at the time of its founding.[6, p.30] The rise of the formation caught many analysts by surprise, as support for Ataka skyrocketed in the days immediately preceding the elections, which was contrary to the expectations of pre-election polls.[7] The results of its first showing at the 2005 Bulgarian national elections were regarded as an accomplishment (for the 
standards of a fringe and newly emerged actor), because it gained 21 seats in the Bulgarian National Assembly (collecting $8 \%$ of the votes). In this way it firmly established a presence in the Bulgarian Parliament by becoming the fourth-largest party, bettering the results of all three of its center-right political rivals. [6, p.27]

In the 2005-2007 periods (before the attainment of the EU membership by Bulgaria in 2007) Ataka's appearance was generally greeted with consternation and derision by the mainstream actors. A clear containment policy was exercised towards Ataka by the other parties in the Bulgarian National Assembly. For instance, all the other relevant parties distanced themselves from any cooperation with Ataka after the nationalists became part of the BNA sessions.[8] In March 2006 Ataka's populist antecedent National Movement for Stability and Progress (NDSV) criticized the destructive tone of Siderov and its "ghastly chauvinism", which "set in apart" from other political blocs in Bulgaria.[8] Ataka's proposals were generally coolly received by the other parties; to take one example, the amendments to the 1998 Law on Bulgarian Citizenship that were suggested by the party in 2006 and envisioned the removal of the right to dual citizenship for non-ethnic Bulgarians were overwhelmingly rejected.[9, p.245] This trend of isolating Siderov's party continued in the later months of 2006 during the Bulgarian presidential elections held in October and November 2006 Siderov was the lone wolf and could not count on the support of the established parties.[6, p.33] The NGOs and human rights groups were no more inclined to treat Ataka with kid gloves. For instance, the president of the Bulgarian Helsinki Committee (BHC) Krasimir Kanev turned the tables on Ataka and placed the ball in its own court by characterizing it as an anti-constitutional. This was due to what he dubbed as racist rhetoric against the Movement for Rights and Freedoms (MRF), allegedly having creeped in during Ataka's questioning of the constitutionality of the Turkish minority party. Kanev even depicted the party's pronouncements as transcending the radicalism exhibited by Jörg Haider and Jean-Marie Le Pen.[7]

There have also been strong indications that Europarties played a significant role in persuading their mainstream Bulgarian national party counterparts not to allow Ataka to cling to any illusions that it could be in a position to govern country. It has been gauged that the delicate pressure (but also accompanied by hints that Bulgaria's EU membership could be compromised) from the European People's Party (EPP), Party of the European Socialists (PES), and others helped shape the attitudes of Bulgarian Socialist Party (BSP), NDSV, and the moderate right-wing parties in Bulgarian politics towards Ataka. These "benign" reminders were arguably attributable to the importance attached by these EU actors to the preemption of a new Haider scenario, possibly in this way attemptting to prevent the headache of future "legitimacy losses" for the EU.[10] One has to recall that the Haider affair (triggered by the January 2000 suspension of bilateral links with Austria by EU member states, following the Freedom Party's inclusion in the new Austrian government) was deemed to have left some serious scars on the EU, especially with regard to the Europeans' perception of its legitimacy. Two of the principal critiques that were raised against the EU sanctions were tied to the dubious legal basis for the EU conduct (implying that the EU had been guilty of unwarranted interference into the domestic order of a state), and the potential backfire effect in terms of empowerment of radical rightist actors within Austria and other European states.[11, pp.25-26] During the pre-accession period the Euro parties did not confine themselves to the mere "coaching" of their Bulgarian partners. In early 2006 a number of MEPs sent out a proclamation, which condemned Ataka and emphasized the need to protect Bulgaria against neo-totalitarianism. [6, p.33] Dutch MEP Els de Groen, who used to be a member of the delegation to the EU-Bulgaria Joint Parliamentary Committee, was possibly the most vociferous in its condemnation of Ataka, branding it as an "offspring of the secret services". [12, p.618]

In addition, there was arguably a natural willingness on the part of mainstream Bulgarian parties (tied to domestic considerations) to oblige and follow the advice of EU actors. One implied impetus for the shunning of Ataka could be linked to the trepidations (especially manifested by the parties in government) that by questioning some of the unwritten rules of the Bulgarian ethnic model, Ataka could sow the seeds of discord between Bulgaria and the EU by encouraging enhanced scrutiny of the former's minority rights record.

Since the fall of communism Bulgaria has displayed pride in being a peaceful country, in which ethnic issues hardly enter the realm of security politics. The emergence of Ataka and its anti-minority rhetoric was viewed as a threat to the attempts of the other parties to keep the matter of inter-ethnic relations in Bulgaria confined to the backstage. [13, p.808]

As early as November 2006 sociologist Teodor Dechev (drawing in part on some of political analyst Ivan Krastev's ideas) identified three possible scenarios for the future development of Ataka.[14] The first one envisioned a disintegration of Ataka due to blows delivered by other nationalistic parties as well as the hostility of the media towards the party. Alternatively, it also foresaw the possibility of Ataka self-sabotaging as a result of internal squabbling over the structure of the party and the accusations of nepotism, which were frequently leveled at Siderov when it came to high-level appointments.[15] The second scenario predicted that Ataka would convert the negative energy from the ill-disposed media and the other parties' accusatory discourses into the garnering of increased sympathy from Bulgarians, which would translate into better electoral showings, in a sense following in the footsteps of the Belgian Vlaams Belang (VB).[15] The third path regarded as favorable to Ataka entailed a gradual integration into the political system of the country. Again, a precedent was cited by the theorist - in Italy, three ostensibly anti-Semitic parties, the Forza Italia (FI), the National Alliance (AN), and the 
Lega Nord (LN), transformed themselves into respectable pillars of the right side of the political spectrum in the country.[15] For instance, the AN's participation in governance succeeded in sufficiently taming the party, in such a way as to cause it to totally drop its anti-systemic rhetoric (though naturally some of the hardline members had to be expunged from the party or left on their own accord to form Social Action (SA) in 2003).[15]

Krastev also hinted at the possibility of a "reduction in the pre-accession Euro-optimism", consequently to be accompanied by a renewed willingness on the part of other parties to include Ataka in a governing coalition, especially with the envisioned role of a "protector of Bulgarian interests within the EU". Thus, he predicted that Ataka's brash anti-systemic rhetoric and radical proposals to counter the perceived irregularities when it came to the decisions taken by/on behalf of the country on its way to accession could become an asset in the aftermath of EU entry, as it could increase the legitimacy of any mainstream party that extended the olive branch to Ataka (due to signaling such a party's intention to be uncompromising in the defense of Bulgarian interests within the EU framework).[15]

Political developments in Bulgaria (especially since 2008) lend some credence to the contention that Ataka is largely following the path outlined by the third scenario. Since the beginning of 2008 Ataka has clamored for acceptance into the EPP and accordingly tended to proclaim its moderation. [16] An interview by Siderov given in July 2009 arguably represented a marked symbolic break with some of Ataka's rather extreme pronouncements in the past. It revealed that Siderov had "socialized" himself and developed a fondness for more diplomatic language in his political discourse. He again played down the radical right-wing parallels by emphasizing that traditional "Christian" conservatism was a defining component of the identity of the party. The Ataka leader was also careful to stay clear of any critique of the neo-liberal economic path that the country had adopted.[16] After the July 2009 national elections in Bulgaria Ataka entered into an informal pact with Bulgaria's election winner Citizens for European Development of Bulgaria (GERB) (the nationalists did not demand any cabinet positions), enabling the latter to sustain a majority in the BNA, so that it could form a government.[17] In December 2009 the party did not raise any serious objections and demonstrated a surprising willingness to compromise, as it dropped its demand for a referendum on the question of whether news in the Turkish language were to be broadcast on Bulgarian national television. This was the result of talks with GERB, the latter itself revealing that the pressure for such an action had come from the EU.[18] In this vein, a visit of an Ataka representative (as part of the GERB leader, Boyko Borisov's delegation) to Turkey in February 2010 was surprisingly well-received by Turkish PM Recep Erdoğan and appeared to have gone to some lengths to reduce the animosity between the party and the Turkish state.[19]
One should not lose sight of the fact that Ataka's opposition not only to the EU membership of Turkey, but also to any presumably pro-Turkish initiatives in Bulgaria, had for a long time been among the cornerstones of its party programme and significantly contributed to the spread of the appeal of its nationalism, so these developments were certainly indicative of a change in its worldview.

Furthermore, Ataka may not have been too concerned that adopting a moderate course could alienate the majority of its adherents. It had reasons to believe that it was in a position to hoodwink its nationalist constituents by claiming that it was not "selling out" in terms of patriotism by proclaiming support for the GERB government (with no strings attached). As stipulated by Minkenberg, "a major part of the agenda-setting capability of rightist actors stems from its potential to alter the parameters of national party competition by forcing mainstream parties into responding to its positions". [20, p.432] Thus, Ataka thought of itself as being in a position to avoid any accusations of nationalist backpedaling, as it could claim to have sufficiently altered the rules of the political game in Bulgaria. The ushering in of new nationalist discourses in Bulgaria in the aftermath of accession (adopted by GERB and BSP) allowed Ataka to argue that nothing precluded it from transforming itself into a system actor (as it did not need to discard its nationalist orientations in order to assume such a position). Siderov must have certainly been thinking along these lines, as in July 2009, in the aftermath of the Bulgarian elections, Ataka expressed satisfaction with the outcome of the elections, citing them as proof that the nationalist platform was now acceptable in Bulgarian politics and cheerfully proclaimed that several parties had "learned" from Ataka's "coaching".[21]

Moreover, Ataka was also treading a familiar path in terms of trying to draw on EU support in order to boost its reputation within the country, which had taken a hit due to members' involvement in some instances of hooliganism as well as the snubs faced from other Bulgarian parties and the media. [22] It is interesting that as early as November 2005 Ataka had attempted to make use of the EU framework to strengthen its political position. On this day it had issued a protest note to the European Parliament (EP) complaining about the "lack of democracy and equal treatment of political parties in Bulgaria" (the underlying reason was the BNA's refusal to allow the nationalists to call themselves "Ataka Party", as well as the removal of their rights to propose legislation). In fact, this instance, albeit not achieving much in terms of alleviating Ataka's situation, is believed to have been the first attempt to involve the EP in domestic political disputes in Bulgaria.[23] In May 2008 Siderov explicitly mentioned that the EU's help could be invaluable in terms of Ataka polishing up its image and restoring its reputation within Bulgaria. The "enabling impact" of the EU (usually utilized when it comes to "providing a reference point" for politicians attempting to orchestrate important breakthroughs, sometimes against deeply entrenched 
persuasions of the wider society), has been well-documented, [24] and it would not be far-fetched to assume that the EU giving the seal of approval to Ataka, could entail similar reputational dividends for the party within the Bulgarian context.

It needs to be noted that contemporary developments in Bulgaria suggest that is not very likely that Ataka could complete the turnaround process and become an acceptable party from the standpoint of the EU mainstream. After breaking ranks with GERB and capitalizing on the anti-monopoly protest wave that gripped Bulgaria in February 2013, which eventually forced the resignation of the First Borisov Government, Ataka initially saw a significant rebound in its electoral fortunes. However, the party's subsequent decision not to vote against the formation of a coalition government between the BSP and the MRF paved the way for the beginning of the Plamen Oresharski cabinet's mandate in May 2013.[25, pp.306-308] This had negative repercussions for Ataka, as it had to contend with losing a significant proportion of its core electorate (due to accusations of an informal alliance with the MRF) and also managed to alarm the EU (because the nationalist party was regarded as a "hidden coalition partner" that could exert influence on the MRF and BSP, which caused pro-EU Bulgarians and EU politicians to be fearful that the country may be going off the rails in terms of its commitment to European values). Ataka's decision to step up its pro-Putin rhetoric (Ataka MPs served as observers at the 2014 Crimean referendum and the party recognized Russia's claim to the peninsula while fully opposing the EU sanctions) in the aftermath of the Euromaidan, also contributed to the public perception regarding the development of a new rift between the nationalist party and most of the mainstream pro-EU political forces in Bulgaria, resulting in a further loss of favour at the EU level. [26]

\section{HZDS}

The People's Party - Movement for a Democratic Slovakia (L'S-HZDS) was established in the early 1990s (initially without the L'S designation) after Vladimir Mečiar abandoned the Public Against Violence (PAV) and created a new political grouping, which eventually crystallized into the HZDS.[24] During that period it was able to find the necessary resonance within Slovak political culture and placated the fears of Slovaks in the aftermath of the Velvet Divorce by weaving together elements of nationalism and promises of conservative economic policies as well as settling for a populist rather than issue-specific rhetoric, with Mečiar's charisma being a contributing factor for its success. [27, pp.278-279]

While it enjoyed a high degree of popular support and the September 1998 elections confirmed the HZDS as the strongest political party in the country, Mečiar's coalition partners did not gain enough votes for a government to be formed, so the pro-EU opposition party Slovak Democratic
Coalition (SDK) was able to assume power.

A number of internal factors were important in reducing the legitimacy of Mečiar prior to the 1998 elections, which resulted in the HZDS moving into opposition. The macroeconomic situation within Slovakia had become very dire.[28, p.279] In an unfortunate twist (from its perspective) the HZDS also helped precipitate its own downfall. It wanted to constrain some of its political opponents, so it amended the electoral law a few months prior to the elections in such a way as to make it obligatory for all parties (even if part of an electoral alliance) to garner at least $5 \%$ of the vote to gain representation. Thus, it provided a very strong incentive for the opposition to be in a cooperative mood and paved the way for their amalgamation into a single entity - the SDK.[29, p.541] In addition, the very high voter turnout $(75 \%)$ was attributable to the well-organized campaigns that warned against voter apathy (i.e. the Civil Campaign OK '98).[30, p.290] While it was initially rather weak, civil society in Slovakia (represented by many NGOs) also managed to pick itself up (with Bratislava and Košice constituting the pro-Western bastions) with the encouragement of leaders of the opposition parties.[31, p.6]

Regarding the EU impact on the outcome of the election, it is always difficult to be separated from the domestic conditions. As maintained by Auer, "Europe's impact is only as strong as domestic actors might make it". Radaelli expresses serious doubts that the EU could ever be in a position to exercise direct influence (i.e. when it comes to democratization initiatives).[32, p.5] Still, the EU factor in the case of Slovakia should not be underemphasized in terms of it being an amplifier when it came to engendering anti-Mečiar mobilization.

From a strictly financial standpoint, in the lead-up to the election the EU and the member states contributed circa $\$ 4$ million for a number of democracy promotion efforts (not only at the level of party leaders, but also lower down the hierarchical ladder).[33, p.31]

The EU also played a significant role as a point of reference for opposition actors; for instance, the SDK never failed to underline the importance of bolstering relations with the EU in order to put an end to Slovakia's isolation in the world."[34, pp.8-9] Henderson likened the 1998 election to an actual referendum regarding Slovakia's EU membership: "The EU issue was not merely of high salience, but also penetrated the core of Slovak party competition to an unusual extent".[34, p.8]

In addition to being instructors when it came to socialization aspects,[35, pp.8-9] the European party families (EPFs) aided Slovak parties (the HZDS and its partners were the only parties that almost operated in a vacuum when it came to links with EU actors) by helping them adopt modern election techniques - for instance, in 1998 the Party of the Democratic Left (SDL) started prioritizing face-to-face conversations with voters in a more personable atmosphere (rather than only sticking to providing information during general meetings).[36, pp.1229-1231] 
On the normative level, an important advantage of these contacts with foreign actors (from the perspective of Slovak parties) was the sense of external solidarity that enhanced their confidence when dealing with the HZDS. For instance, Mečiar was more reluctant to subvert the electoral rules (as evinced by the backfiring of the 1994 attempted expulsion of the Democratic Union (DU) from the Slovak Parliament) when aware that a certain party was well-connected in Western circles.[36, p.1233]

In this regard, in Eduard Kukan's view (former leader of the DU and MEP) the transnational activity was also important in enhancing the Slovaks' willingness to critically engage in politics rather than to unthinkingly follow the instructions of leaders.[36, p.1244] Thus, the EU arguably exerted some influence in terms of helping remove certain cultural stigmas such as the natural reluctance to oppose influential leaders among lower-ranked party functionaries and the general populace.[36, p.1244]

Lastly, the role of the EPFs as information providers is not to be underestimated. As established previously, in the pre-election phaseMečiar had frequently attempted to shift the goalposts by blaming the opposition for Slovakia's sinking reputation in the EU. In addition, from a nationalist standpoint, to avoid the humiliation that he had brought Slovakia to the position of a "laggard" in the EU accession process, Mečiar tended to emphasize that the other CEE states were in a comparable situation to that of Slovakia. However, the presence of strong linkages with the EU actors helped the opposition to see right through Mečiar's attempts to mollify the Slovaks (i.e. by illuminating the reality that Slovakia was far behind the other accession candidates) and this understanding trickled down to their constituents. It is essential to remember that one of the underlying philosophies behind the effectiveness of political conditionality has to do with a reliance on the natural competitive instinct of countries (especially neighbours) as an encouragement to complete the acquis.[37, pp.8-9]

Thus, Mečiar's issue was that he had been failing not only in his quest to make Slovakia a "standard" member of the European family of nations, but also in his race with Slovakia's neighbors within the CEE region.[28, p.285]

In essence, the EU was careful to sugar-coat its statements, tactfully distinguishing between the HZDS government and the country of Slovakia, thus as a whole managing to reassure the Slovak public of the magnanimity of its intentions. For instance, in the spring of 1998 while in Slovakia and addressing the stalling tactics of Mečiar, Hans van den Broek (at the time the EU Commissioner for External Relations) reiterated that: "the question is not whether Slovakia will enter the EU, but when this will take place. The answer is in the hands of the Slovak government.'"[38, p.9]

All in all, the power shift in Slovakia might have occurred even without the presence of EU influence, but it is very much likely that the EU helped sustain a degree of unity among the Slovak opposition and handled itself well in refraining from blacklisting Slovakia as a whole when it came to the country's prospects for admission.

In the aftermath of the HZDS' fall from grace, rather than falling under the spell of "hard" Euroskepticism, the party appears to have gone in the opposite direction. In the 1998-2000 period, it arguably displayed "façade benevolence" towards the EU (as its actions did not really correspond with the official pronouncements).

In the initial transformative stage after 1998 at least on the surface the HZDS appeared to have disarmed the anti-European hardliners within the party.[39, pp.170-171] Fittingly, it started taking pot shots at its former ally, the Slovak National Party (SNS), lambasting its anti-EU stances. In a 2000 book, of which Mečiar himself was the publisher, he reiterated his enthusiasm for European integration, even jumping on the bandwagon of the "United States of Europe" notion, expressing his support for both an elected European central government and EP.[40, p.9] At the 2000 Trnava Congress Mečiar also appeared to discard the nebulous populist package (which tended to be off-putting for the Europarties), maintaining that the HZDS had adopted the profile of a "slightly rightist" political party.[40, p.9] The 2003 rebranding of the HZDS as LS-HZDS, was generally associated with a further shift in the direction of more conservative tenets.[41, p.192] In his political declaration at Trnava, Mečiar further declared that the attainment of the EU (and the NATO) accession was to be the ultimate aim of Slovak foreign policy.[41, p.198]

In 2007 Mesežnikov classified the party as "undoubtedly pro-integrationist and pro-Atlantic", and during the same year HZDS pronouncements clearly demonstrated that it was not able to identify any alternatives to NATO and the EU when it came to the provision of security within Europe.[41, p.198] In addition, more recently (in 2008) the HZDS followed suit with the other Slovak parties in refraining from expressing significant interest in the reinvigoration of close ties with other Eastern European countries such as Russia within the framework of the EU, thus demonstrating that it had expunged the "eastern vector" foreign policy aspirations from its system.[42, p.22]

After the HZDS was disestablished in 2014, the SNS remains one of the main exponents of Slovak nationalism. It has traditionally utilized anti-Hungarian rhetoric, but during the campaigning for the 2014 European Parliament elections it jumped on the generic Eurosceptic bandwagon, focusing on the perceived shortcomings of the EU. Other more moderate Slovak parties have voiced business-oriented criticisms of the EU as well as deplored the threats emanating from the EU level when it comes to the preservation of traditional Christian values.[43] In any case, hard Euroscepticism in Slovakia continues to be at best a fringe phenomenon.[44]

\section{Conclusions}

Having provided a detailed look into the workings of two parties, which scholars have generally tended to place into the nationalist-populist side of the political spectrum and 
which have been frequently branded as anti-democratic, a number of final observations could be made. The analysis of the attitudes towards the EU exhibited by the Slovakian HZDS and the Bulgarian Ataka testifies to the fact that hardcore Euroskepticism (implying a total rejection of the European integration project itself and often of the democratic system of governance associated with it) seems to be lacking fertile ground for developing and being politically successful in the case of the "new wave" entrants (the countries that became members of the club through the 2004 and 2007 enlargements). Ataka and the HZDS exemplify an interesting trend with regard to CEE parties that are ostracized by the EU - instead of allowing the resentment for the EU due to its restructuring of their domestic political space to their detriment, they allow themselves to be Europeanized and gradually carve out a niche within a more moderate (even if still somewhat anti-establishment territory). It is also worth exploring whether the fact that nation-branding strategies are underdeveloped (or perceived to be so) in Eastern Europe [45, pp. 194-195] as compared to the Western side of the continent is a factor in encouraging a more critical look at one's own country's problems and represents a snag with regard to rejecting the EU in full even among parties that are opposed to the EU's core principles.

This paper concentrated exclusively on party-based Euroscepticism in Eastern Europe while bracketing the examination of the Eurosceptic developments in the western part of the continent. This may lead one down a false path lined with exuberant optimism pertaining to the gravity of the threats posed by EU-opposing parties to the future of the Union. However, a quick glance at the political situation in quite a few Western European states reveals that the year 2014 was actually characterized by a plethora of successes for Eurosceptic forces, most notably for the Front National (FN), United Kingdom Independence Party (UKIP) and the Danish People's Party (DPP), which amassed the most votes at the European Parliament elections.[46] Another EU-wide trend (at least among the "old" member states) is connected to the mainstreaming of extreme right and Eurosceptic discourses,[47] as manifested in the United Kingdom, in particular in the case of the British Conservative Party and its emerging receptiveness (David Cameron made such a pledge in early 2013) to the idea of a referendum on Britain's membership in the EU.[48] With Brexit somewhat unexpectedly becoming a reality after the British people voted by a slight margin for the country to leave the European Union in the June 2016 EU membership referendum, the stage has been set for the invocation of Article 50 of the Treaty of Lisbon by the UK and the unleashing of wide-ranging political centrifugal forces that could fundamentally redefine the nature of the EU. Thus, the biggest challenge to the continued existence of the EU in its present is unlikely to be found at the eastern reaches of the continent.

The majority of the Eastern European states' lukewarm reactions to the EU involvement in the Ukrainian crisis and the sanctions imposed on Russia notwithstanding, Russophilia and pro-EU sentiments are seen as being able to go hand in hand without any apparent cognitive dissonance. This applies even in the case of the countries such as Bulgaria that enjoy a special relationship with Russia from a historical standpoint.[49] The populist phenomenon in its Eastern European manifestation is not as of yet comparable in terms of a non-negotiable anti-EU potency to its Western European version.[50]

\section{REFERENCES}

[1] Taylor, Paul and Robin Emmott. Euroskeptic election surge gives EU a headache, Reuters, 26 May 2014.

[2] Ellison, David L. In the Face of Uncertainty: EU Membership and the Quest for Convergence, Swedish University of Agricultural Science, 2003.

[3] Dechev, Teodor. The counterattack against Siderov and his future in politics, News bg, 26 October 2006.

[4] Sgourev, Stoyan V. The Explosive Rise of a Political Party: the Logic of Sudden Convergence, in European Sociological Review, pp. 1-16, August 2009.

[5] Dnevnik. Valeri Simeonov was unanimously reelected as chairman of the NFSB, 6 December 2014.

[6] Ghodsee, Kristen. Left Wing, Right Wing, Everything Xenophobia, Neo-totalitarianism and Populist Politics in Bulgaria, in Problems of Post-Communism, Volume 55, pp. 26-39, 2008.

[7] Yotova, Boryana. Ataka - the surprising competitor at the elections? Mediapool bg, 21 June 2005.

[8] Terzieva, Ekaterina and Galya Goranova. The third coalition partner also condemns Ataka's nationalism, Sega bg, 6 March 2006.

[9] Smilov, Daniel and Elena Jileva. Country Report: Bulgaria, EUDO Citizenship Observatory, European University Institute, Florence, Italy, January 2010 (revised April 2010).

[10] Andreev, Aleksandar. The Experiment with "Ataka", Dnevnik newspaper, 25 May 2009.

[11] Howard, Marc Morjé. Can Populism be suppressed in a Democracy? Austria, Germany and the European Union, in East European Politics and Societies, Volume 14, No. 2, pp. 18-32, 2000.

[12] Spirova, Maria. The parliamentary elections in Bulgaria June 2005, in Electoral Studies, Volume 25, Issue 3, pp. 616-621, September 2006.

[13] Spirova, Maria. Euro parties and party development in EU-candidate states: the case of Bulgaria, in Europe-Asia Studies, Volume 60, Issue 5, pp. 791-808, July 2008.

[14] Krastev, Ivan (interview). Elites with a clock mechanism, Kultura newspaper (Issue 3), 27 January 2006.

[15] Dechev, Teodor. Three scenarios regarding the future of Ataka, 2 November 2006.

[16] Dikov, Ivan. Bulgaria Nationalist “Ataka" party leader Siderov: I cannot be a follower of Hitler, Novinite.com, June 26, 2009. 
[17] Enchev, Velizar. The triple coalition bastardizes the nation GERB, Ataka and the Blues destroy science, Desant, 17 May 2010.

[18] 24 Hours. No referendum, but no wedge has been driven between Ataka and GERB, 20 December 2009.

[19] Vlaykova, Kalina. The Turkish state came to realize that Ataka is not as dangerous as commonly perceived, 24 hours, 4 February 2010.

[20] Rydgren, Jens. Is Extreme Right-Wing Populism Contagious? Explaining the Emergence of a New Party Family, in European Journal of Political Research, Volume 44, Issue 3, pp. 413-437, May 2005.

[21] IRI. Bulgaria Post-election Watch: July 2009 Parliamentary Elections.

[22] Budakova, Liubomira and Ruslan Yordanov. Happy mingling with the justice system, Tema News, 2007.

[23] Terziev, Svetoslav. Ataka with the first complaint against Bulgaria in the EP, Sega bg, 30 November 2005.

[24] Diez, Thomas and Stephan Setter. The European Union and the Transformation of Border Conflicts: Theorizing the Impact of Integration and Association, International Workshop on Europe's Borders, July 2004.

[25] Lilov, Grigor. The Most Affluent Bulgarians, Caylas EOOD Publishers, Sofia, Bulgaria, 2013.

[26] Mediapool. Five Ataka members will be travelling to Crimea as observers for the referendum, 14 March 2014.

[27] Dyson, Kenneth H.F. (ed.) The Euro at 10: Europeanization, Power, and Convergence, Oxford University Press, 2008.

[28] Kopecký, Petr. Parliaments in the Czech and Slovak Republics - Party Competition and Parliamentary Institutionalization, Ashgate Publishing Company, UK, 2001.

[29] O’Dwyer, Conor. Runaway State-Building: How Political Parties Shape States in Postcommunist Eastern Europe, in World Politics, Volume 56, pp. 520-553, July 2004.

[30] Bunce, Valerie and Sharon Wolchik. International Diffusion and Postcommunist Electoral Revolutions, in Communist and Postcommunist Studies, Volume 39, No. 3, pp. 283-304, September 2006 (Special Issue on Democratic Revolutions in Postcommunist States).

[31] Marček, Eduard. Dialogue between the Government and Civil Society in Slovakia, PANET, 2008.

[32] Philips, Tony and Stefan Auer. Europeanization, MEPs and the case of the Hungarian minority in Slovakia, Working Paper, La Trobe University.

[33] Deegan-Krause, Kevin. Elected Affinities - Democracy and Party Competition in Slovakia and the Czech Republic, Stanford University Press, USA, 2006.

[34] Mišík, Matúš. Slovak Way to the European Union - the 1998 and 2002 Elections, 2nd ECPR Graduate Conference, Barcelona, Spain, August 2008.

[35] Dakowska, Dorota. The Mechanisms of EU Enlargement Impact on Polish Political Parties: The Case of New
Members' Association to European Party Federations and the Transnational Activity of German Political Foundations, ECPR Joint Session Workshops, Turin, Italy, 22-27 March 2002.

[36] Pridham, Geoffrey. Complying with the European Union's Democratic Conditionality: Transnational Party Linkages and Regime Change in Slovakia, 1993-1998, in Europe-Asia Studies, Volume 51, Issue 7, pp. 1221-1244, November 1999.

[37] Anastasakis, Othon. The Politics of Extremism in Eastern Europe: A Reaction to Transition, in Papeles del Este, Issue 3, pp. 1-15, 2002.

[38] Vachudova, Milada. Democratization in Post-communist Europe: Illiberal Regimes and the Leverage of International Actors, Center for European Studies Working Paper Series \#139, 2005.

[39] Haughton, Tim. HZDS: The Ideology, Organization and Support Base of Slovakia's Most Successful Party, in Europe-Asia Studies, Volume 53, Issue 5, pp. 745-769, 2001.

[40] Van Duin, Pieter and Zuzana Poláčková. Submission, Survival, Salvation: the Political Psychology of Nationalist Populism in post-communist Slovakia, Conference on Populism, Graz, Austria, 2001.

[41] Král, David, Věra Řiháčková, and Tomas Weiss. Views on American Foreign Policy: The Atlanticism of Political Parties in Central and Eastern Europe, EUROPEUM Institute for European Policy, 2008.

[42] Rybáŕ, Marek and Kevin Deegan-Krause. Slovakia's Communist Successor Parties in Comparative Perspective, in Communist and Post-Communist Studies, Volume 41, pp. 497-519, 2008.

[43] Výrostková, Lucia. Slovakia's Eurosceptics end EU honeymoon, EU Observer, 2 May 2014.

[44] Krasnovsky, Tomas. Ukraine crisis - killing Euroscepticism in Eastern Europe?, The New Federalist, 3 June 2014.

[45] Kaneva, Nadya and Delia Popescu. National Identity lite: Nation branding in post-Communist Romania and Bulgaria, in International Journal of Cultural Studies, Issue 14, pp. 191-204, 2011.

[46] The Globe and Mail. Eurosceptic election surge threatens governments across EU, 26 May 2014.

[47] Mondon, Aurélien. The Front National in the Twenty-First Century: From Pariah to Republican Democratic Contender, Workshop on the Nationalistic Right, University of Bath, United Kingdom, 1 February 2013.

[48] Ross, Tim. David Cameron: my seven targets for a new EU, The Telegraph, 15 March 2014.

[49] Mediapool. An increasing number of Bulgarians express dislike towards Russia in the aftermath of the Ukrainian crisis, 16 March 2015.

[50] Decker, Frank (ed.). Populismus: Gefahr für die Demokratie oder nützliches Korrektiv? (Populism - a threat to democracy or a needed check?), Verlag für Sozialwissenschaften, 2006 